\title{
KEPEMIMPINAN DALAM PERUBAHAN ORGANISASI PERPUSTAKAAN PERGURUAN TINGGI
}

\author{
Khilal Syauqy \\ Fakultas Adab IAIN Imam Bonjol Padang \\ khilal_syauqy@gmail.com
}

\begin{abstract}
Success in the organizational change is determined by leadeship, because leadership with leader is who implementing and planning change. This paper is aimed at obtaining information to related the effect of leadeship with many aspeks on organizational change. Based on those teories reveals that some aspecs of leadersip with (1) visionary leader, (2) comunicator leader, (3) leader as change agent, (4) (leader as coach) and leader as Technology information analysis,could be enhanced and improved organizational change. Therefore this aspecs can be used for achieved organizational change special at University libraries.
\end{abstract}

Keywords: Leadersip, Organizational Change

\section{Pendahuluan}

Era globalisasi telah mengubah dunia menjadi seakan tanpa batas, perkembangan ilmu pengetahuan kian pesat dan pada waktu yang sama di tempat yang berbeda informasi dapat diperoleh dengan mudah. Sebagai konsekuensi logis terjadilah ledakan informasi yang tentunya memerlukan suatu teknologi yaitu teknologi informasi untuk dapat mengakses dan menyebarluaskan informasi tersebut dengan cepat.

Pesatnya kemajuan teknologi informasi dewasa ini berdampak cukup luas terhadap semua lini kehidupan, termasuk kehidupan organisasi salah satunya adalah organisasi perpustakaan perguruan tinggi. Ditambah lagi dengan kehidupan masyarakat global yang penuh tantangan menuntut organisasi perpustakaan perguruan tinggi dengan segenap potensi dan misi mampu menempatkan diri dalam konteks lingkungan strategis yang selalu berubah.

Perpustakaan perguruan tinggi sebagai pusat dokumentasi dan informasi serta sumber literatur mendukung Tridharma Perguruan Tinggi dalam pendidikan dan pengajaran, penelitian dan pengabdian pada masyarakat.

Perpustakaan adalah yang pertama merasakan dampak dari ledakan informasi, karena untuk menyimpan, mengelola dan menyebarluaskan informasi tersebut menjadi tanggungjawab perpustakaan.. Kehadiran Teknologi Informasi telah merubah wahana penyampaian informasi di perpustakaan dari berbasiskan kertas dan cetak menjadi multi media, di samping itu sistem pelayananpun berubah dari manual ke otomasi Sehubungan dengan itu sudah saatnya suatu perubahan pada organisasi perpustakaan

dioptimalkan yang secara spesifik berupa perubahan teknologi dalam bentuk otomasi perpustakaan. Perubahan pada organisasi perpustakaan perguruan tinggi merupakan sebuah ekspektasi dalam era globalisasi ini dan hendaklah dapat dimanifestasikan 
dalam bentuk aplikasi Teknologi Informasi.

Perubahan organisasi bisa berupa perubahan teknologi, struktur, individu dan fisik yang membutuhkan pengetahuan, keterampilan serta budaya baru. Dalam melakukan perubahan terhadap organisassi banyak factor yang menghambat perubahan tersebut termasuk budaya organisasi yang menolak akan perubahan serta kepemimpinan yang lemah. Pernyataan tersebut didukung oleh pendapat Daff (1988: 659) bahwa kepemimpinan dapat mendorong serta mendukung kreatifitas untuk membantu pengikut dan organisasi agar lebih menerima serta siap berubah. Selanjutnya penelitian Bishop (2001: 2020-227) menyatakan bahwa pimpinan pada tingkat puncak memfasilitasi kemampuan untuk perubahan dalam tingkatan mendukung serta mengembangkan kemampuan untuk perubahan. Hasil penelitian tersebut menyiratkan bahwa semakin kuat kepemimpinan seseorang dalam melakukan tindakan untuk perubahan organisasi maka akan semakin tinggi tingkat tercapainya perubahan organisasi, sebaliknya semakin lemah kepemimpinan seseorang dalam mempengaruhi dan menggerakkan orang lain untuk melakukan perubahan, maka semakin rendah pula tingkat tercapainya perubahan.

Pengaruh dan tanggung jawab kepemimpinan seperti yang disebutkan di atas sudah barang tentu menuntut pengetahuan, keterampilan, profesional, dan latar belakang pendidikan tinggi. Khusus untuk kepemimpinan perpustakaan perguruan tinggi, yang akan mengimplementasikan Teknologi Informasi sebagai suatu perubahan, pendidikan mereka seharusnya S2 ilmu perpustakaan dan minimal sarjana perpustakaan, karena semasa pendidikan, mereka cukup dibekali dengan ilmu dan keterampilan aplikasi teknologi informasi untuk perpustakaan. Namun pada kenyataan sebagian besar jabatan pimpinan perpustakaan perguruan tinggi khususnya di Sumatera Utara lebih mengacu pada kepangkatan tanpa latar belakang pendidikan ilmu perpustakaan. Hal tersebut terungkap melalui pengumpulan data (survei penulis tahun 2014 terhadap 21 perpustakaan perguruan tinggi di Sumatera Utara) pimpinan perpustakaan yang berlatar belakang pendidikan S2 sebanyak 4,76\%, S1 19,05\%, Diploma3 $4,76 \%$, dan $71,43 \%$ dengan latar belakang non sarjana ilmu perpustaan. Kondisi ini yang mungkin meyebabkan sebagian kepemimpinan perpustakaan belum mampu membawa organisasinya pada perubahan dengan konsep pemanfaatan teknologi informasi.

Dalam konteks ini timbul pertanyaan konsep kepemimpinan yang bagaimana yang cocok dan dapat membawa organisasi pada perubahan? Sehubungan dengan permasalahan tersebut penulis berupaya memberikan solusi yang berlandaskan pada teori dan konsep kepemimpinan yang dapat membawa organisasi pada perubahan. khususnya dalam implementasi teknologi informasi pada perpustakaan perguruan tinggi yang akan dibahas berikut ini.

\section{Pembahasan Perubahan Organisasi (Organizational Change)}

Untuk memahami perubahan organisasi secara teoretis, penulis mengumpulkan beberapa definisi dan konsep para ilmuan. Michel Beer (2000: 452) menyatakan berubah itu adalah memilih tindakan yang berbeda dari sebelumnya, perbedaan itulah yang menghasilkan sustu perubahan. Jika pilihan hasilnya sama dengan yang sebelumnya berarti akan memperkuat status quo yang ada. Selanjutnya 
Winardi (2005: 2) menyatakan, bahwa perubahan organisasi adalah tindakan beralihnya sesuatu organisasi dari kondisi yang berlaku kini menuju ke kondisi masa yang akan dating menurut yang di inginkan guna eningkatkan efektivitasnya. Sejalan dengan itu Anne Maria (1998: 209) berpendapat, bahwa perubahan organisasi adalah suatu tindakan menyusun kembali komponenkomponen organisasi untuk meningkatkan efisiensi dan efektifitas organisasi.

Mengingat begitu pentingnya perubahan dalam lingkungan yang bergerak cepat sudah saatnya organisasi tidak menunda perubahan, penundaan berarti akan menghadapkan organisasi pada proses kemunduran. Akan tetapi perlu diingat bahwa tidak semua perubahan yang terjadi akan menimbulkan kondisi yang lebih baik, sehingga perlu diupayakan agar perubahan tersebut diarahkan kearah yang lebih baik dibandingkan dengan kondisi yang sebelumnya.

Pendapat yang senada dikemukakan oleh JO. Bryson (1990: 374) seorang pakar dalam manajemen perpustakan menyatakan bahwa "when one or more elements in a library change it is called organizational change" Pendapat Bryson tersebut menunjukkan bahwa salah satu unsur saja dalam organisasi yang berubah, sudah dapat dikatakan sebagai perubahan organisasi.

Dari beberapa definisi tentang perubahan di atas dapat ditarik pengertian bahwa perubahan organisasi itu merupakan suatu tindakan yang dilakukan terhadap unsur-unsur dalam suatu organisasi untuk meningkatkan efektivitas organisasi menuju ke arah yang lebih baik daripada sebelumnya. Perubahan merupakan bagian dari kehidupan manusia, dan dapat juga terjadi pada organisasi termasuk organisasi perpustakaan.

Perpustakaan sebagai organisasi nirlaba tidak dapat terhindar dari perubahan, kehadiran perkembangan teknologi informasi merupakan dorongan eksternal yang utama akan merubah unsur-unsur dari organisasi perpustakaan. Setiap organisasi mempunyai target perubahan yang berbeda sesuai dengan kebutuhan dan faktor dominan yang mendorong perubahan tersebut, begitu juga perubahan pada perpustakaan perguruan tinggi termasuk perubahan yang direncanakan yang diakibatkan oleh dorongan teknologi informasi.

Sehubungan dengan itu Bryson (1990: 374-375) menjelaskan bahwa perubahan yang mendasar pada organisasi perpustakaan adalah:

1. Perubahan teknologi yang meliputi otomasi perpustakaan pada bidang: proses pengatalogan, pelayanan pemakai dan sistem pengadaan bahan pustaka, Sistem penelusuran informasi seperti CD-ROM dan OPACs, internet.

2. Perubahan struktur, sebagai hasil dari komputerisasi yang meliputi spesialisasi kerja, wewenang, departementalisasi dan rentang kendali.

3. setting fisik, meliputi letak tata ruang, desain interior, fasilitas penempatan peralatan sesuai dengan kebutuhan kerja.

Pernyataan Bryson tersebut lebih memperjelas bahwa perubahan organisasi perpustakaan yang utama adalah pemanfaatan teknologi informasi yang secara otomatis akan merubah struktur dan penataan pisik dan individu (people) di perpustakaan.

Sebagaimana yang dijelaskan di atas bahwa untuk melaksanakan perubahan organisasi di perpustakaan 
perguruan tinggi tidaklah mudah, kepemimpinan merupakan factor kunci dalam menentukan suksesnya suatu organisasi menuju perubahan. Berikut ini akan dibahas lebih luas tentang konsep kepemimpinan perubahan yang berlandaskan pada teori.

\section{Kepemimpinan}

\section{a. Pengertian Pemimpin}

Kepemimpinan merupakan salah satu unsur penentu keberhasilan organisasi, terlebih lagi dalam menuju perubahan. Untuk memahami apa yang dimaksud dengan kepemimpinan (leadership) ada baiknya terlebih dahulu mengetahui arti pemimpin (leader). Hal ini disebabkan kepemimpinan dilakukan oleh seorang pemimpin dan ia mengemban tugas dengan beraktivitas untuk melaksanakan kepemimpinan tersebut.

Menurut Robbert D Stuart (2002: 352) bahwa pemimpin adalah seorang yang diharapkan mempunyai kemampuan untuk mempengaruhi, memberi petunjuk dan juga mampu menentukan individu untuk mencapai tujuan organisasi. Seiring dengan itu James P. Spillane (2006: 10) menyatakan bahwa pemimpin itu agen perubahan dengan kegiatan mempengaruhi orang-orang lebih daripada pengaruh orang-orang tersebut kepadanya.

\section{b. Konsep Kepemimpinan}

Beragam definisi dan konsep kepemimpinan yang ditemukan dalam berbagai bahan pustaka, yang masingmasing berbeda dalam penekanan arti. Richard L. Daf (2005: 5) mendefinisikan kepemimpinan (leadership) adalah suatu pengaruh yang berhubungan antara para pemimpin dan pengikut (followers). Kemudian Gibson menyatakan bahwa kepemimpinan adalah suatu upaya menggunakan pengaruh untuk memotivasi orang-orang guna pencapaian suatu tujuan.

Masih berhubungan dengan pengaruh, Ken Blanchard yang dikutip oleh Marcelene caroselli (2000: 9) menyatakan bahwa kunci untuk kepemimpinan hari ini adalah "pengaruh" bukan "kekuasaan" selanjutnya ia mengatakan para pemimpin tahu bagaimana mempengaruhi orang-orang dan membujuk mereka untuk suatu tuntutan pekerjaan yang tinggi.

\section{c. Konsep Kepememimpinan Perubahan}

Pada dasawarsa akhir ini, kepemimpinan lebih populer dengan kepemimpinan perubahan. Richard L. Daff mengemukakan konsep kepepemimpinan dalam satu definisi saja yaitu "kepemimpinan adalah merupakan suatu pengaruh hubungan antara pimpinan dan pengikut (followers) yang bermaksud pada perubahan dan hasil nyata yang mencerminkan tujuan bersama" Dari definisi tersebut tercakup tujuh unsur yang esensial dalam kepemimpinan, (1) pemimpin (leader), (2) pengaruh (Influence), (3) pengikut (Follower), (4) maksud (Intention), (5) Tujuan bersama (shared purpose), (6) Perubahan (change), (7) tanggung jawab pribadi (Personal responbility).

Pengaruh adalah hubungan timbal balik bukan satu arah antara pemimpin dengan pengikut dengan maksud dan harapan terjadi perubahan yang berarti sebagai hasil dari tujuan bersama. Dari pandangan Daff di atas dapat dipahami bahwa pengaruh tidak dikaitkan dengan unsur kekuasaan maupun paksaan yang dilakukan pemimpin terhadap bawahan. Pemimpin mempengaruhi bawahan dan juga bawahan dapat mempengaruhi 
pemimpin, malahan menurut Daff pengikut yang baik bukanlah "Yes people" kadangkadang pemimpin yang efektif sama dengan dengan pengikut yang efektif, hanya berbeda dalam memainkan perannya. Kemudian unsur tanggung jawab pribadi dan integritas (personal responbility and integrity) menunjukkan adanya tanggung jawab antara pimpinan dan orang-orang yang ada dalam organisasi harus sama-sama mempunyai tanggung jawab penuh untuk mencapai tujuan. Sedangkan unsur perubahan (change) merupakan hasil dari pimpinan dan pengikut yang menjadi harapan masa depan dan mereka sama-sama menciptakan perubahan, bukan memelihara status quo. Atau dengan kata lain perubahan adalah gambaran dari tujuan bersama (shared purpose).

Jika dicermati ketujuh elemen kepemimpinan yang dikemukakan oleh Daff, terkandung makna penting, bahwa antara pimpinan dan pengikut tidak terdapat perbedaan yang nyata dalam memberikan pengaruh dan tanggung jawab untuk mencapai perubahan. Yang berbeda adalah peran antara pemimpin dan pengikut.

Dari beberapa definisi dan konsep kepemimpinan di atas terlihat bahwa kepemimpinan pada artinya merupakan adanya kegiatan/aktivitas mempengaruhi dan menggerakkan orang lain untuk bekerja sama dalam rangka mencapai tujuan bersama, apakah tujuan itu berupa perubahan organisasi dan sebagainya.

Sehubungan dengan itu, Burt Nanus (1999: 18) menemukan model khusus yang digunakan untuk memahami peran pemimpin organisasi non profit yang diwujudkan dalam kegiatan, yaitu:

1) Dalam organisasi (Inside the organization), peran pimpinan berinteraksi dengan staf dan tenaga sukarela untuk memberikan inspirasi, mendorong, menggerakkan dan memberdayakan mereka.

2) Ke luar organisasi (outside organization), peran pimpinan mencari bantuan, dukungan dari donatur, mitra yang berpotensi dengan para pimpinan bisnis di luar organisasi.

3) Pada masa operasi (present operation), pimpinan memusatkan pada kualitas dan pelayanan, pada struktur organisasi, sistem informasi dan aspek lainnya.

4) Kemungkinan masa depan (on future possiblities), pimpinan mengantisipasi trends serta mengembangkan arah masa depan organisasi.

Keempat hal tersebut terdiri dari enam peran yang merupakan aktivitas pemimpin dalam menjalankan kepemimpinannya dan oleh Burt digambarkan sebagai berikut:

Ke luar organisasi

$$
\downarrow
$$

Politisi dan Memberi Visi dan Juru kampanye Strategi Masa

Kemungkinan Operasi Masa Depan

Pelatih Agen Perubahan Dalam Organisasi

Gambar - 2.6: Peran Pemimpin

Organisasi Nonprofit

Sumber: Burt Nanus. Leaderrs Who

Make a Diffrence for Meeting the non

Profit Challenge (1999: 18)

\section{Keterangan gambar:}

1) Peran 1 dan 2: pemimpin sebagai pemberi visi dan strategi (visionary and strategies), maksudnya pemimpin adalah seorang yang bertanggung jawab untuk menggerakan organisasi ke arah yang benar. Kemudian 
pemimpin

menyebarkan

menetapkan,

dan

mengembangkan visi dengan

jelas serta menunjukkan cara-

cara baru di masa yang akan datang. Di samping itu ia memberikan inspirasi pada anggotanya serta mendesain strategi untuk mencapai visi dan misi organisasi.

2) Peran 3 dan 4: Pemimpin sebagai politisi dan juru bicara (politician and champaigner), artinya pemimpin berperan sebagai penasehat, juru bicara dan sebagai negosiator terhadap bawahannya. Ia juga membangun hubungan dengan menggunakan sumber-sumber informasi (super networker)

3) Peran 5: Pemimpin sebagai pelatih (coach), maksudnya didalam diri pemimpin telah tertanam sifat membangun regu dan membina orang-orang dalam organisasi, ini merupakan tanggungjawabnya. Selain itu pemimpin juga berperan membangun kepercayaan yang menjadi pegangan organisasi dan ia juga pemberi semangat serta inspirasi pada setiap individu.

4) Peran 6: pemimpin sebagai agen perubahan (change agent) dalam posisi untuk masa yang akan datang. Ia mempunyai pengaruh besar dalam pengambilan keputusan untuk perubahan dan ia memperkenalkan programpraogram baru, menciptakan strategi kerja sama dengan publik. Kadang-kadang ia seorang restruktur organisasi dan seorang inovator.

Sebagai agen perubahan, pemimpin adalah individu yang bertanggung jawab untuk mengubah sistem dan tingkah laku anggota organisasi. Dalam pelaksanaan pemimpin dapat menggunakan model empat langkah Lewin. Kurt Lewin dan Schein mereka berpendapat bahwa perubahan yang sukses dalam organisasi hendaknya mengikuti empat langkah, (1) keinginan untuk berubah (desire of change), sebelum perubahan terjadi setiap individu harus merasakan suatu kebutuhan, dapat berupa kekurangan-kekurangan dan ketidakpuasan selama ini serta adanya keinginan untuk meningkatkan, (2) pencairan (unfreezing), yang meliputi memberikan dorongan, membujuk melalui pendekatan-pendekatan dengan mengurangi ancaman-ancaman maupun penolakkan sehingga setiap individu siap untuk berubah, (2) merubah (changging) yang meliputi pemberian perubahan pada setiap individu melalui pembelajaran baru pada sikap mereka, dalam hal ini pekerja diberi informasi baru, model perilaku baru, dan cara baru dalam melihat sesuatu sehingga pekerja belajar dengan sikap baru. dan (3) memantapkan (refreezing) perubahan baru untuk membuat jadi permanen.

Di samping itu Peter Hernon, Ronald R (2003: 131) menyatakan bahwa untuk menilai kepemimpinan organisasi perpustakaan akademik, pemimpin bertindak sebagai (1) strategi visi dan tujuan untuk organisasi perpustakaan, (2) orang yang memberikan kontribusi pada kampus, (3) inisiatif dan kreatif, (4) membangun anggotanya, menjaga moral dan memberikan inspirasi.

Definisi kepemimpinan yang dikemukakan baik Burt, maupun Peter Hernon, pada dasarnya adalah sama, semua poin yang dikemukan Burt juga terdapat dalam poin yang diajukan Peter. Pemimpin yang dapat menganalisa pemanfaatan teknologi 
merupakan unsur yang amat penting (urgent) dalam kepemimpinan perubahan dan harus diperhitungkan, apalagi bagi kepemimpinan perpustakaan perguruan tinggi yang menuju ke perubahan dalam bidang teknologi informasi. Bagaimana mungkin seorang pemimpin perpustakaan tidak dapat berperan atau tidak menguasai teknologi informasi.

Merujuk pada konsep kepemimpinan di atas, yang dimaksud dengan kepemimpinan adalah aktivitas/kegiatan atasan dalam mempengaruhi dan menggerakkan orang lain untuk mencapai tujuan organisasi dengan aspek-aspek, (1) pimpinan yang memberikan, mengembangkan dan menyebarkan visi (visioner), (2) sebagai komunikator, (3) menjadi agen perubahan (change agent), (4) sebagai pelatih (coac) dan (5)dapat menganalisa pemanfaatan teknologi informasi.

Konsep kepemimpinan berserta indikatorindikator di atas, dikumpulkan dari teori-teoti yang dianggap dianggap cocok untuk membawa organisasi pada perubahan, karena untuk suatu perubahan pemimpin harus seorang yang visioner, dan dapat berperan sebagai change agent, dapat mengkomunikasikan perubahan baik ke luar maupun ke dalam organisasi, ia harus menguasai teknologi informasi sehingga ia akan dapat bertindak sebagai pelatih dari bawahannya. Kepemimpinan perubahan akan berhasil apabila ia kuat dan mampu menjalankan perannya seperti yang disebutkan di atas, di samping itu beberapa teori menyatakan bahwa kepemimpinan melalui pimpinannya berpengaruh langsung terhadap perubahan organisasi hal ini sangat mendukung untuk pimpinan tersebut melaksanakan perannya.

\section{Pengaruh Langsung Kepemimpinan terhadap Perubahan Organisasi}

Pengaruh

kepemimpinan

terhadap perubahan dinyatakan Hersey (2000: 491) bahwa pemimpin yang berpengaruh, tidak melaksanakan perubahan dalam kondisi fakum, akan tetapi perubahan itu disempurnakan dengan hati-hati melalui penciptaan berbagai bagian. Selanjutnya Hersey menjelaskan bahwa dengan pertimbangan dan pandangan terhadap factor-faktor yang mempengaruhi suksesnya perubahan, dampak-dampak positif dapat diusulkan untuk terjadinya perubahan tersebut.

Pendapat Anne Maria (1998: 217), "Organizational change is an important topic for manager, because a substantial part of their jobs requires the information and implementation of planned organizational change" pendapat tersebut menunjukkan bahwa perubahan organisasi yang direncanakan menjadi bagian dari tugas seorang pimpinan. Menurut Gibson (2006: 502) Apabila pada suatu kasus pimpinan melaksanakan perubahan, dia harus mengantisipasi penolakan terhadap perubahan dan mempersiapkan serta mengatasinya.

Tentang adanya pengaruh langsung kepemimpinan terhadap perubahan organisasi diperkuat oleh Yulkl (2002: 300-301) bahwa seorang pemimpin dapat berbuat banyak untuk memfasilitasi kesuksesan pelaksanaan perubahan, melalui tindakan politik termasuk menciptakan koalisi, membentuk tim, memilih orang yang tepat untuk diletakkan pada posisi kunci, membuat simbol perubahan, dan memonitor serta mendeteksi persoalan yang harus diperhatikan.

Di sisi lain Daft (2005: 659) menambahkan, bahwa pemimpin dapat mendorong dan mendukung kreatifitas untuk membantu pengikut dan 
organisasi agar lebih menerima serta siap berubah. Pandangan Peter Hess, tentang pengaruh kepemimpinan terhadap perubahan melalui tanggung jawab pemimpin dalam menggerakkan orang-orang, yaitu "change is leadership respobility. The challenge is to move people beyond their evensiveness and resistance to the point where they view change not as threat but as an opportunity"

\section{Penutup}

Untuk merencanakan dan mengimplementasikan perubahan organisasi diperlukan kepemimpinan yang kuat melalui tindakan pimpinan dalam mempengaruhi, mengarahkan anggota organisasi untuk mencapai perubahan. Berdasarkan teori tindakan tersebut tercermin di dalam aspek-aspek kepemimpinan, yaitu pimpinan yang dapat, (1) memberikan, mengembangkan dan menyebarkan visi (visioner), (2) sebagai komunikator, (3) menjadi agen perubahan (change agent), (4) sebagai pelatih (coach) dan (5) menganalisa pemanfaatan teknologi informasi.

Sehubungan dengan itu untuk mendapatkan pimpinan perpustakaan perguruan tinggi yang tepat dalam mewujudkan suksesnya perubahan organisasi, strategi yang terbaik adalah: Melalui rekrutmen terhadap orangorang baru yang memenuhi persyaratan berdasarkan pada aspek-aspek kepemimpinan yang diinginkan. Untuk mendapatkan pimpinan yang visioner, langkah yang diambil adalah, secara berkala pimpinan universitas mengharuskan pimpinan perpustakaan membuat rencana strategis minimal untuk lima tahun ke depan. Kemudian hasil kerja mereka dinilai menurut kriteria yang ditetapkan oleh tim khusus. Kesempatan ini hendaknya diberikan juga kepada pimpinan divisi, dengan konsekuensi bagi mereka yang yang memenuhi kriteria atau mempunyai visi yang dapat membabawa organisasi pada perubahan dipromosikan menjadi pimpinan perpustakaan.

Pemimpin sebagai pelatih termasuk salah satu aspek dari kepemimpinan yang perlu ditingkatkan. Apalagi perubahan utama dalam organisasi perpustakaan adalah perubahan pada teknologi informasi (otomasi perpustakaan). Dalam hal ini, dibutuhkan seorang pimpinan yang dapat menganalisa teknologi informasi, membimbing dan mengarahkan bawahannya untuk tidak canggung menerapkan teknologi informasi.

Untuk ini latar belakang pendidikan mereka sebaiknya S2 ilmu perpustakaan atau minimal sarjana perpustakaan. Suatu langkah yang dapat dilakukan adalah, dengan merekrut lulusan program studi ilmu perpustakaan yang diselenggarakan di dalam negeri seperti di USU, UI, UNPAD dan UNHAS, maupun lulusan luar negeri. Bagi pimpinan lama yang belum mendapat pendidikan ilmu perpustakaan diperlukan perhatian dari pimpinan universitas untuk memberikan fasilitas dalam melanjutkan pendidikan maupun pelatihan pada bidang ilmu perpustakaan.

Untuk pemimpin bertindak yang bertindak sebagai agen perubahan, dibutuhkan seorang pimpinan perpustakaan yang dapat mengkomunikasikan keuntungan serta pentingnya suatu perubahan baik ke dalam maupun ke luar organisasi Hal ini dapat dilakukan melalui tulisan di majalah kampus, poster, dan ceramah.

\section{Daftar Pustaka}

Beer, Michael. Breaking the Code of Change, USA: President and 
Fellow of Harvard College, 2002.

Bryson, JO. Effective Library and Information Centre Management, England: Gower, 1990.

Bishop, Charles H Jr. Making Change Happen one person at a time: assessing change within your organization, New York: AMACOM, 2001.

Caroselli, Marcelene, Leadership Skill for Managers, New York: McGraw-Hill, 2000.

Daff, Richard L, The Leadership Experience. Canada: Thomson, 2005.

Daff, Richard, Management, Chicago: The Dryden Press, 1988

Gibson, James L at all., Organizations: behavior, structure, Prossesses, Boston: McGraw-Hill, 2006.

Hernon, Peter; Ronald R. Powell and Arthur P. Young. The Library leadership: attributes of academic and Public Director, London:: Libraries Unlimited, 2003.

Hersey, Paul; Kenneth h.Blanchard; Dewey E.Johnson. Management of Organizational Behavior: utility human resources, New Yersey: Prentice Hall, 1996.

Nanus, Burt and Stephen M. Dobbs. Leaders Make Different Strategies for Meeting the Non Profit Challenge, San Francisco: Jossey bass, 1999.
Spillane, James p. Distributed leadership, San Francisco: Jossey Bass, 2006.

Stuart, Robert D. and Barbara B. Morgan. Library and information centre management, USA: Library Unlimited, 2002.

Yulk, Gay A. alih bahasa Jusuf Udaya. Kepemimpinan dalam Organisasi, Jakarta: Prenhallindo, 1998. 
8 Jurnal al-Tsaqafa Volume 13, No. 01, Januari 2016

!

Halaman sengaja untuk dikosongkan 